Providence. Connecticut:-Nichols, Wilton. Georgia:-Augusta. Utah:-Sugar, Tennessee:-Cagle. Kansas:-Lawrence. New Jersey:- New Brunswick. Washington, D. C. Massachusetts:-Amherst, Worcester, Lawrence, Andover, Methuen. The three last are new localities.

In England, at Hereford, in 1890 , on Ribes sanguineum. (Morgan). It is also found in Canada, being included in the check-lists of inserts of the Dominion of Canada, compiled by the Natural History Society of Toronto and published in 1883 . [Henshaw].

Chionaspis furfurus has been cited as being found at New Mexico (Bull. No. 3, N. M., Agr. Exp. Sta., Jan. I89I); but Prof. Cockerell assures me that it has never been found there. Walsh in Practical Entomologist, vol. I, p. 64, I866, lists it as being very common on willow in Illinois. And Riley in American Naturalist, 1881, vol. I5, p. 487, received them on raspberry from Oxford, Miss. There is, perhaps, some doubt as to the identification of the scales on these food plants.

Chionaspis furfurus Fitch is a native species, and was first observed by Harris in I $84 \mathrm{I}$, and was named by Fitch in 1856 . It has been commonly known as the scurfy bark louse and Harris bark louse, and cited by many authors as Aspidiotus furfurus, $A$. cerasi, Coccus harrisii, Aspidiotus harrisii and Diaspis harrisii.

PosTsCrIPT. - Since the above was written, I have received the following, kindly furnished me by Prof. James Fletcher of Ottawa, Canada. Chionaspis furfurus has been received from Nova Scotia, New Brunswick, and Prince Edwards Island, and many have been imported on nursery stock. It is not an uncommon species, but at the same time by no means of frequent occurrence throughout Ontario west of this point to the Niagara Peninsula and up to Lake Huron and Georgia Bay. It has not been received from British Columbia.

\title{
DESCRIPTION OF THE LARVA OF CALOCAMPA CURVIMACULA.
}

\author{
BY HARRISON G. DYAR, WASHINGTON D. C.
}

I received these eggs through Dr. Ottolengui under another name, but the determination was corrected by breeding. The mature larva has been briefly described by Dr. Thaxter. The generic term Calocampa is utterly inapplicable to this species, as the larvae are plain, ordinary noctuids, far from "beautiful."

$E g g$. Hemispherical, rounded below, the flat base small; strongly vertically ribbed, beaded, with ring-like micropyle. There are about 40 ribs around the base, but they diminish in number upward, not confluent and are finely beaded. Diameter .8 , height $.5 \mathrm{~mm}$.

Stage I. Head rounded, pale brown, not shining; width $.4 \mathrm{~mm}$. Body slender, gait. slightly looping, the abdominal feet of joints 7 and 8 much smaller than the others. especially on joint 7 . Joint $\mathrm{i} 2$ a little enlarged. Body smooth, light gray, food visible; tubercles large, nearly black, circular, iv equidistant between iii and $v$, vi not present; setae dark, distinct, but short. Cervical shield brown; no anal plate. After feeding the larvae became pale green.

Stage II. Head pale greenish; width .6 $\mathrm{mm}$. Body long, slender, feet of joints 7 and 8 very small; not shining sordid green with narrow white dorsal, subdorsal and broader stigmatal lines, none very distinct. Tubercles minute; setae distinct, dark, normal. Segments very indistinctly annulate.

Stage III. Head whitish green, not shin. 
ing; ocelli black, mouth faintly brown; width I mm. Body green; dorsal line straight, white, crinkly edged; tubercles $i$ and ii white; subdorsal line straight, narrow, white; tubercles iii and iv less distinctly white; substigmatal line distinct white, moderately broad, somewhat shaded below, just covering spiracles. Feet green, those of 7 and 8 smaller than the others. Tubercle iv opposite lower edge of spiracle.

Stage IV. Head $1.8 \mathrm{~mm}$. All pale green, joint 22 a little enlarged; feet nearly equal. Lines and tubercles white, dorsal and subdorsal lines narrow, rather pulverulent; stigmatal moderate, enclosing the spiracles except on joints 2 and 12 , a dark green shade above it reaching to tubercle iii. Feet green, shields and plate uncornified, obscure. Tubercles minutely black in white rings; iv at the lower edge of spiracle; setae rather long, fine, dusky. Spiracle white, finely black rimmed.

Stage $V$. Head green, ocelli narrowly black centrally, labrum white; width $2.7 \mathrm{~mm}$. Green, plates invisible; skin finely white dotted, lines white; dorsal line distinct, obsolete at the ends ; subdorsal narrow, faint, half as wide as the dorsal; stigmatal narrow, about the width of the spiracles which it half encloses except on joints 2 and 12 , covering tubercle iv; a dark green shade above, diffuse, fainter at the spiracles. Subventer white dotted; feet clear green, equal. Body slender, joint 12 slightly enlarged. Tubercles and spiracles white, the latter ringed.

Stage VI. Head pale brown, shining, reticulate with darker brown, shaded in clypeus and at base of antennae; labrum whitish; ocelli pale; width $4.6 \mathrm{~mm}$. Body cylindrical, joint is a little enlarged on top; feet equal. Light yellow-brown; dorsal and subdorsal lines narrow, pulverulent and broken, brownish white, bordered with darker brown; oblique subdorsal shades brown, running between tubercles $\mathrm{i}$ and $\mathrm{ii}$ forward and outward; skin mottled, dotted with whitish; substigmatal line moderately broad, whitish on the edges, centrally of the color of the body, the lower edge finally fading out, leaving a very narrow pale line cutting the spiracles. Feet pale; setae white; cervical shield and anal plate not cornified, not lined. Spiracles white, black ringed. Later the larvae fade to a pale greenish brown, the lines becoming faint and the head appearing dark by contrast. Setae single, normal, iv opposite lower edge of spiracle.

The larvae hatched early in May and entered the earth in June. They fed on various leaves, but seemed to prefer willow, on which they throve. The imagoes appeared in August.

\section{FOUR NEW SPECIES BELONGING TO THE GENUS PLENO- CULUS FOX.}

BY William H. AShMEAD, Washington, D. C.

The genus Plenoculus Fox was erected in Psyche, Vol. VI, I 893, p. 554, with one species $P$. davisi. Since that time, however, four additional species have been described, three by Fox and one by myself. I have now the pleasure of presenting descriptions of four new species and giving a table for distinguishing all of the species.
The genus is unknown outside of boreal North America.

Table of Species.

Clypeus anteriorly not emarginate medially . . . . . . . . 2

Clypeus anteriorly emarginate, or excised medially, dentate or denticulate laterally. 

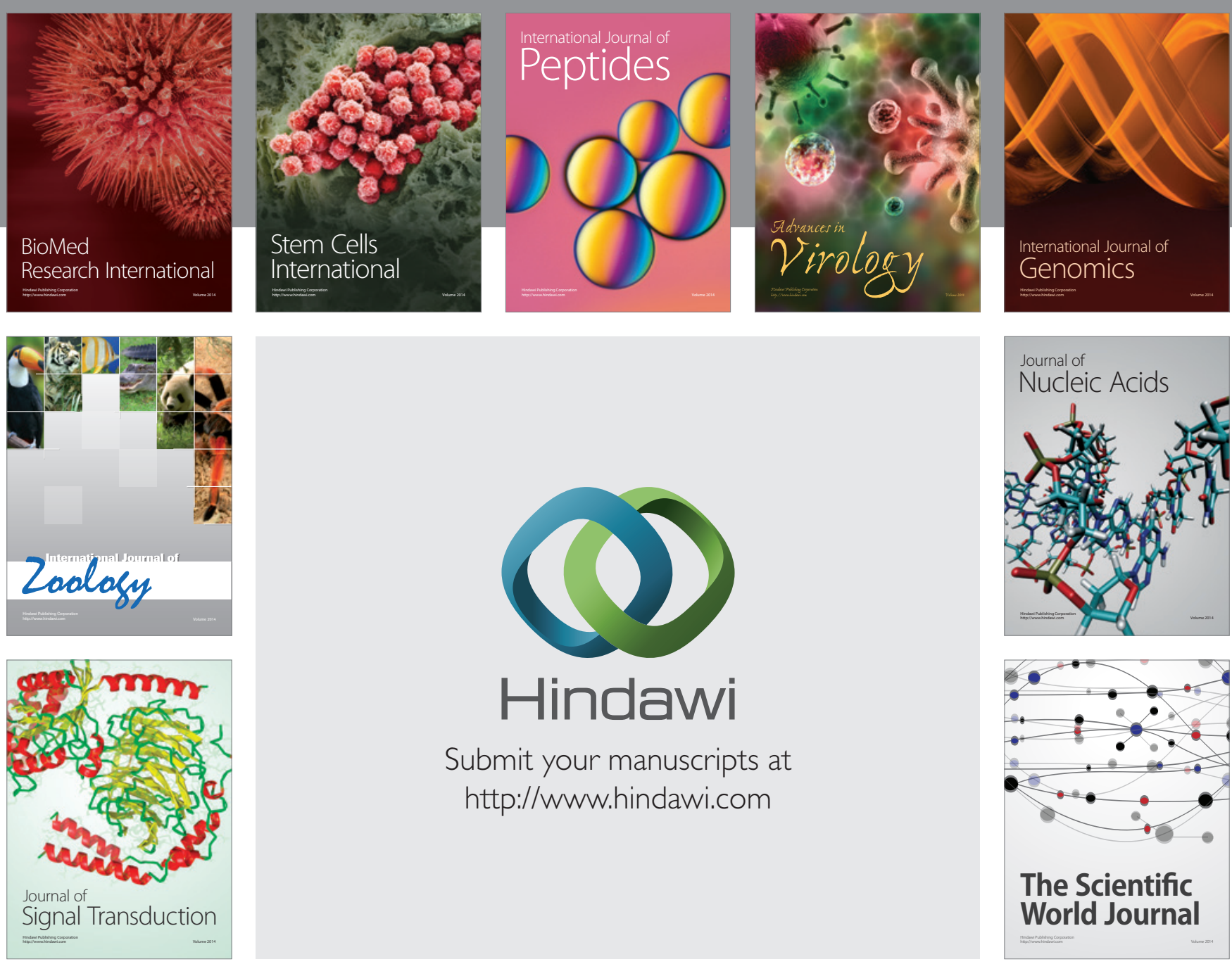

Submit your manuscripts at

http://www.hindawi.com
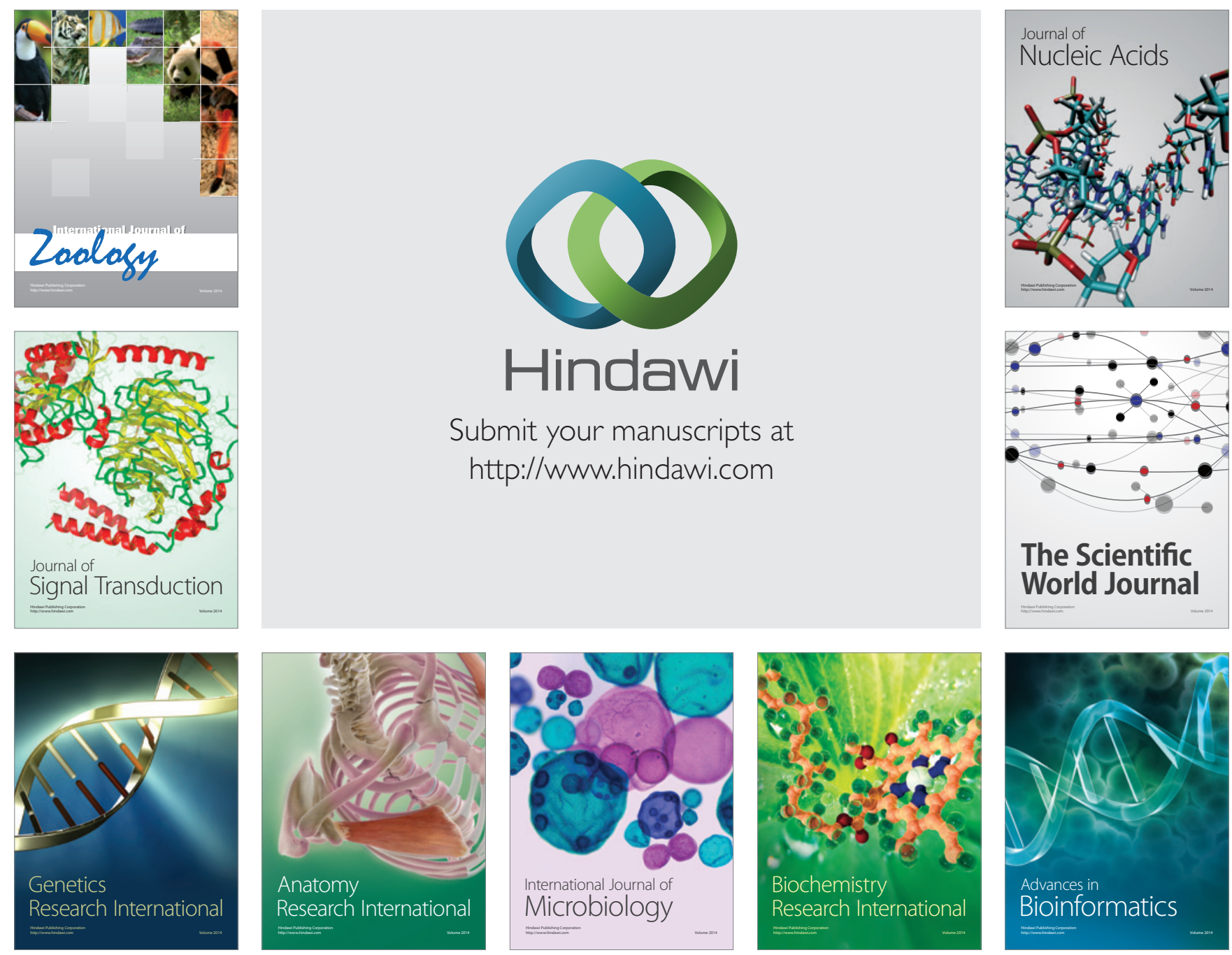

The Scientific World Journal
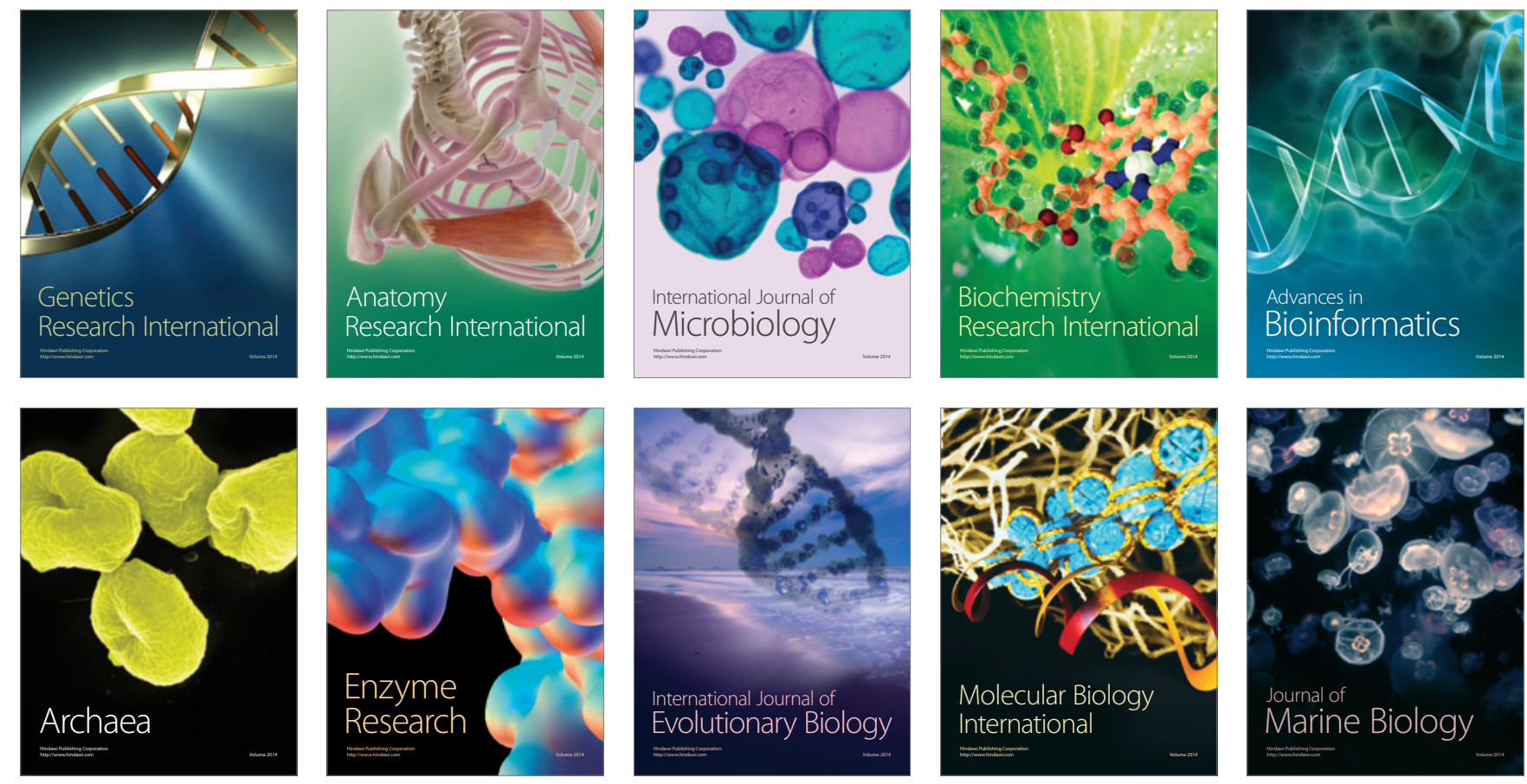